\title{
Business Metaphors in a Bilingual Business Lexicon*
}

\author{
Li Lan(eglilan@polyu.edu.hk) and Grahame T. Bilbow \\ (eggrabil@polyu.edu.hk), Department of English, Hong Kong Polytechnic \\ University, Hong Kong
}

\begin{abstract}
General purpose dictionaries benefit users at large in many ways, but the definitions and examples might not satisfy the diverse needs of different professional users. This is especially true of metaphors. The article discusses the treatment of business metaphors in the PolyU Business Lexicon derived from the trilingual PolyU Business Corpus (PUBC). During the process the concordances are grouped by senses, and then separated according to their literal and metaphorical meanings, which in turn lead to the decisions of sense order, word meaning and translation equivalents. Since different cultures have different 'bags' of metaphors, and metaphorical meanings also vary in different registers, the focus is primarily on the differences between Chinese and English in terms of culture, psychology, language and how such differences can be translated and presented in a corpus-based business lexicon with a minimum loss of their original connotations. Cultural transformations, such as direct translation, image substitution, explanatory notes and abandonment of the figure of speech, are suggested to bridge interlanguage metaphorical gaps.
\end{abstract}

Keywords: METAPHOR, DEFINITION, TRANSLATION, CULTURAL DIFFERENCE

Opsomming: Sakemetafore in 'n tweetalige sakewoordeboek. Woordeboeke vir algemene doeleindes bevoordeel gewone gebruikers op baie maniere, maar die definisies en voorbeelde mag dalk nie die uiteenlopende behoeftes van verskillende professionele gebruikers bevredig nie. Dit is veral waar van metafore. Die artikel bespreek die behandeling van sakemetafore in die PolyU Business Lexicon gebaseer op die drietalige PolyU Business Corpus (PUBC). Gedurende die proses word die konkordansies deur betekenisse gegroepeer, en dan geskei volgens hul letterlike en metaforiese betekenisse, wat vervolgens lei tot die besluite oor betekenisorde, woordbetekenis, en vertaalsekwivalente. Aangesien verskillende kulture verskillende "sakke" metafore het, en metaforiese betekenisse ook varieer in verskillende registers, is die fokus primêr op die verskille tussen Sjinees en Engels in terme van kultuur, psigologie, taal en hoe sulke verskille vertaal en aangebied kan word in 'n korpusgebaseerde sakewoordeboek met ' $n$ minimum verlies aan hul oorspronklike konnotasies. Kulturele transformasies, soos direkte vertaling, beeldvervanging, verklarende aantekeninge en prysgewing van die stylfiguur, word voorgestel vir die oorbrugging van die tussentalige metaforiese gapings.

Sleutelwoorde: METAFOOR, DEFINISIE, VERTALING, KULTURELE VERSKIL

* This article is an adapted version of a paper presented at the International Conference on Translation and Bilingual Dictionaries at the Chinese University of Hong Kong, Hong Kong, 23-24 February 2002.

Lexikos 12 (AFRILEX-reeks/series 12: 2002): 171-180 
Metaphor is an important linguistic expression of analogy, and the study of metaphor helps us understand the social systems and structures that shape languages. Lakoff pointed out that metaphor is not just a part of novel poetics but very much a part of everyday, ordinary language. He also argued that metaphor is not merely a matter of language but a matter of thought; consequently, it is an inseparable part of the manner in which the world is ordinarily conceptualized (Lakoff 19932: 46). In the course of creating the PolyU Business Lexicon, which is based on the PolyU Business Corpus (PUBC) (see Li and Bilbow 2001), it was noticed that the metaphorical use of words has a high frequency of occurrence but their meanings are hard to be found in reference works. Take, for example, the following two sentences:

1. The Dow Industrials Average, which jumped 132 points the past three trading days, was higher in early US trade, enabling the FTSE to flirt with the 4,300-point level for the first time in two weeks.

2. Big companies such as stockbroker Merrill Lynch and retailer Wal-Mart Stores are beginning to flirt with the concept.

The definition of flirt in the Cambridge International Dictionary of English (CIDE) is ' 1 . to behave as if sexually attracted to someone, although not seriously ; 2 . (flirt with) to consider, although not seriously'. These meanings from a general dictionary do not fit into the above sentences, and a specialized dictionary, Longman Dictionary of Business English does not include the word flirt. It was assumed that general dictionaries cannot embody all the specific meanings of a word, and specialized ones might rule them out as general English words. The assumption was borne out by looking up a number of metaphorically used verbs in PUBC. The following is an example from the English-Chinese Dictionary, one of the most authorative bilingual dictionaries published in China:

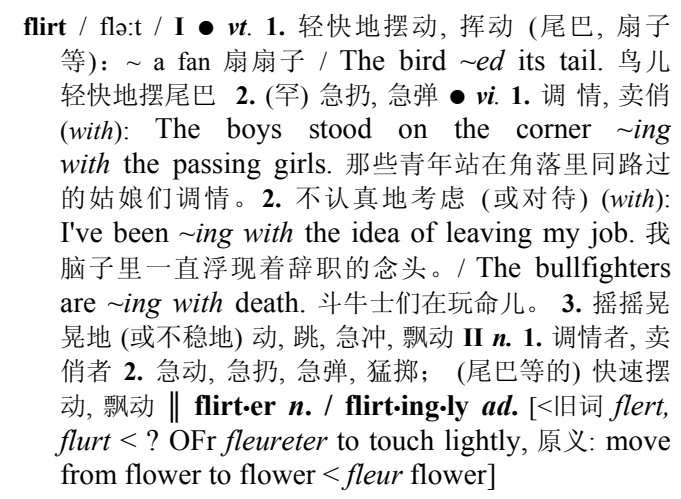

Semi-technical words like flirt are often polysemic and metaphorical. The sense order of such words in a general dictionary is often arranged according to the 
frequency of occurrences, therefore its meaning in a specific register might be buried in the huge amount of information, and its metaphorical meaning can be even more difficult to find. To fill the gap between general dictionaries and specialized dictionaries, it was decided to embody both highly specific terms and semi-technical words in the word list of the Business Lexicon and to record the meanings that emerge from the business corpus only. The word flirt has little sexual connotation in the PUBC corpus, therefore its definition was settled as 'to experiment with'.

\section{Analysis of business metaphors}

Business texts are a rich source of metaphorical language. There has been a renewed upsurge of interest in describing metaphor in general, and in understanding the metaphorical models, paradigms or images that shape and construct business knowledge, practices and structures. In The Language of Metaphors, Goatly (1997: 46-53) groups metaphorical patterns in the English lexicon as follows:

-- general reifying: including create, destroy, transform, transfer, handle, possess, impact, space, place, proximity, dimension, shape, parts, perception and seeing.

- $\quad$ specific reifying: physical properties can figure as abstract qualities.

- $\quad$ animizing and personifying: abstract entities are represented not simply as concrete, but as animate and human.

- $\quad$ materializing abstract process: internal mental processes are metaphorically represented as perceptual processes.

All these patterns exist in the PolyU Business Corpus. The metaphors are based on certain image-schemata which recur in our everyday experience, e.g. containers, paths, balance, up and down, part and whole, front and back. However, the nature of business leads us to map business metaphors into several conceptual or master metaphors: business as a war, as a game, as a machine, as a human being and as a plant. Each category has a graded structure, with some prototypical category members being more central than others. It is also noted that the process of word-formation involves metaphor, and metaphors operate as nouns, verbs, adjectives, adverbs or as longer idiomatic phrases (Baldick 1990: 134).

\section{Meaning}

'Dictionaries are certainly the cemeteries and the mortuaries, definitely the dormitories, and generally the resting place for the populations of metaphors' (Goatly 1997: 31). Although inactive metaphors have become lexicalized, acquired a new conventional semantic meaning and found their way into diction- 
aries, active metaphors are highly dependent on inferential pragmatic principles connected with language use and users in contexts. Active metaphors are more difficult to define and translate.

Metaphorical interpretation in business texts demands experience of language either through the process of metaphorical transfer, or through the narrowing or extending of senses. Look at a group of metaphors referring to water:

Verb: pour, flood, flow, dry up, sank, plug, swim, dive.

Noun: source, drain, fluid, liquidity.

With the help of the information offered by the business corpus, these metaphors can be lexicalized with exact and unambiguous explanations relating to business contexts. For instance:

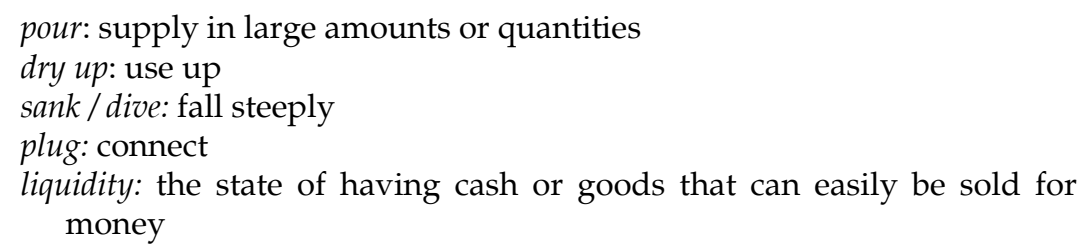

However, the degree of metaphoricity of the above words is lower than that of the words curb, cushion, shruggle and mount, which require more, what Andersen calls, 'metaphor-competence'. The strategy of understanding such metaphors includes the linguistic manifestation of the metaphor, its identification and interpretation, and its differences from and similarities to other linguistic signs (Andersen 2000: 58). For instance, metaphors indicating trends, or updown metaphors, are highly relevant to the field of business. Normally up is better and down is worse. However, up is not always better. When the metaphors mount and escalate are used, they describe costs, debts, inflation or unemployment. Up is definitely worse in these cases and the definition and translation should reflect this.

\section{Sense order}

In the PUBC, the majority of warfare items are used metaphorically and only a very small portion is used literally. Therefore, in the creation of the lexicon, it was attempted to draw users' attention directly to the metaphorical senses of words in definitions and in translation equivalents. For instance, of the 97 occurrences of the verb attack, only a few actually describe military or physical action (shown in bold in the concordance below).

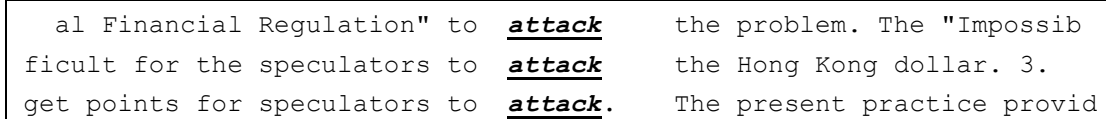




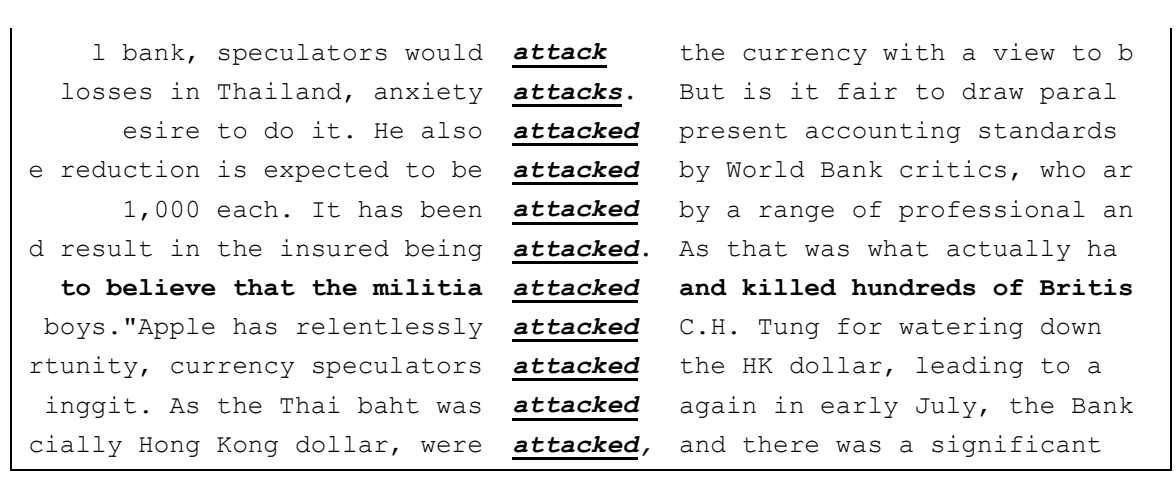

The lexicon entry for the verb attack is therefore as follows:

attack vt.

1. to attempt to harm someone or something

2. to criticize strongly and negatively

3. to take aggressive physical action against someone or something

It is interesting to note how polysemous words find their way into the business lexicon. According to the concept of common core vocabulary, a word has a central meaning and a series of radiations. Radiations from the core are multidimensional, stretching out in all directions. Consequently, there are differences in terms of the degree of 'closeness to the core' of a group of polysemes. When compiling a general language dictionary, the editor may try to cover as many dimensions as possible. In a specific domain, in contrast, word radiation tends to be mono-dimensional; therefore, when working on a specific dictionary, one direction might meet the criteria for inclusion.

The core meaning of the word strategy, for example, is 'the art of planning in advance the movements of armies or forces in war' (Oxford Advanced Learner's Dictionary), and its extended meaning is 'a detailed plan for achieving success in situations such as war, politics, business, industry or sport, or the skill of planning for such situations' (CIDE). In the Business Lexicon, only the extended meaning of strategy is included.

Metaphorical use in business discourse also tends to limit the inclusion of synonyms and antonyms in the Business Lexicon. For example, there is only limited metaphorical aptness for words such as assault and strike, which are normally considered synonyms of the word attack, to collocate with the words currency, market, accounting standard, etc.

\section{Picture in another language}

When metaphors occur in different cultures, the cognitive prototype may be the same, may be partially the same or may be totally different. Mühlhäusler 
notes that natural metaphor tends to be culture-dependent and universally understood, in contrast to culturally invented neutral metaphor. As such, metaphor may provide important insights into language universals: 'Developmentally very early clusters of meaning (archetypal metaphor) may reflect universals in the semantics of human languages' (Mühlhäusler 1983: 19).

It is obvious that many discussions on metaphor translation focus on the conviction that 'metaphor is text' (Snell-Hornby 1988). But in compiling a dictionary or a lexicon, 'one-word metaphor' has to be dealt with. Such translation is not the simple task of converting thoughts and words into the words of a different language or discipline, and then changing them back again into similar concepts represented by different, but equivalent, words. Sherblom argues that translation is transformative in nature rather than simply translative, and is a larger, more encompassing, dynamic, communication process: 'As a transformative business communication phenomenon, translation becomes a more complex process engaged in by whole communities and cultures' (Sherblom 1998: 75). As the word list of the PolyU Business Lexicon is generated from the English corpus as base, interest lies mainly in identifying how English metaphor translates into Chinese or Japanese, not in identifying metaphorical equivalents across all three languages.

Three strategies have been adopted when translating business metaphors in the PolyU Business Lexicon:

-- direct translation,

-- image substitution, and

-- abandonment of the figure of speech.

\section{Direct translation}

Because all human beings have the same basic perceptual apparatus and share many similar experiences, it is inevitable that there are some strong similarities in metaphorical structure across languages. The first and most satisfying procedure for translating metaphor is to reproduce the same image in the target language, provided it has comparable frequency and currency in the appropriate TL register (Newmark 1988: 108). Direct translation is used when both source language and target language have the same or similar cognition of metaphors.

Human metaphors have many similarities across languages. For example, organizations have heads in both English and Chinese. A handshake and 握手言和 both mean 'the reaching of an agreement'; to shoulder a loss or a responsibility has the Chinese equivalent 肩負. English and Chinese-speaking business people both suffer from headaches, 頭痛, and fevers, 過熱. The metaphorical verb to slam also has a direct equivalent in Chinese meaning 'to criticize severely'.

Many warfare metaphors in business are also translated directly into Chinese. 


$\begin{array}{ll}\text { bidding war } & \text { 奪標戰 } \\ \text { mortgage war } & \text { 按揭戰 } \\ \text { price war } & \text { 削價戰 } \\ \text { mortgage rate war } & \text { 按揭減息戰 } \\ \text { MPF war } & \text { 強積金戰 }\end{array}$

\section{Image substitution}

Another common procedure for translating metaphor is replacement of the image with another established TL image. Parent in English can be regarded as gender-free. The Chinese term for parent company, however, is 母公司 (mother company), not 父母公司 (father and mother company) or 雙親公司 (parents company). Infant companies are different from a term common in Chinese, 子公司 (literally son company or subsidiary, having no equivalent in English), as the following example illustrates.

Conversely, venture capital can play a different role in funding risky infant companies.

Infant, as used in infant company, infant insurance industry, etc., has no equivalent in Chinese. The definition of infant company then takes on an extended meaning of 'newly-established company or business'.

Chinese has a metaphorical use of the verb to swallow which means 'to tolerate something that is unpleasant'. For example, the expression 'swallow a bitter pill/bitter wine' refers to tolerating a situation rather than swallowing a specific object or liquid. Chinese does not, however, permit the expressions to swallow high costs, interest rates or risks. In this case, the translation has to have its extended meaning: 吸收, 忍受.

Partial coverage occurs in some cases. For example, the verb to ignite has the same extended meaning in Chinese but it most often occurs in political texts, and only rarely in business texts. In English, however, the verb to ignite appears quite commonly, as in the following example:

Fears for further interest rate rises were ignited on Thursday when slightly higher-than-expected US gross domestic product data for the first quarter indicated rising inflation.

\section{Abandonment of the image}

According to the New Oxford English Dictionary, lobby refers to any of several large halls in the Houses of Parliament in which MPs may meet members of the public. The verb sense (originally US) derives from the practice of frequenting the house of a legislature to influence its members into supporting a cause. In the PUBC English corpus, for example, the following is found: 
Why firms lobby, they argue, is due to government intervention which has an effect on their cash flows.

This sense of the word lobby is, however, absent in Chinese culture. The Chinese translation in dictionaries is 大廳, 休息廳 (entrance hall), which has neither a political sense nor a verbal function. Its verbal figurative speech has, therefore, to abandon the image of lobby and is translated as 游說, 拉票.

Shrug off is a body gesture that is common among Westerners to show indifference or dismissal. It is not, however, a common gesture among Chinese. The expression to show indifference in Chinese is 不屑一顧 (not worth one glance), relating to eye movement. From the following business context, we have opted to use the expression 漠視, 擺脫 in the lexicon.

\begin{tabular}{|c|c|c|}
\hline $\begin{array}{l}\text { UK equity market was able to } \\
19 \text { per cent this week alone, } \\
\text { the next millennium must be } \\
\text { ers said Hong Kong stocks had } \\
\text { per cent firmer. Investors } \\
\text { a ebbed, the Hong Kong market } \\
\text { ofitable in 1998. Mr Wang }\end{array}$ & $\begin{array}{l}\text { shrug } \\
\text { shrugged } \\
\text { shrugged } \\
\text { shrugged } \\
\text { shrugged } \\
\text { shrugged } \\
\text { shrugged }\end{array}$ & $\begin{array}{l}\text { off some of the uncertainty } \\
\text { off early selling pressure to } \\
\text { off with a laugh. } \\
\text { off a weak Wall Street overnigh } \\
\text { off the news from New York, s } \\
\text { off higher closes on Wall Stree } \\
\text { off worries that the ethylene }\end{array}$ \\
\hline
\end{tabular}

The following is a concordance of the word foot from the PUBC English corpus:

\begin{tabular}{|rll}
\hline y, don't get caught with your & $\underline{\text { foot }}$ & in your mouth - visit our Ja \\
said. Foreign firms eye & $\underline{\text { foot }}$ & in door of lucrative pension \\
re-based consultancy to get a & $\underline{\underline{\text { foot }}}$ & in doors now closed to fore \\
uing it would force them to & $\underline{\underline{\text { foot }}}$ & the insurance bill for their \\
s and generally would have to & $\underline{\underline{\text { foot }}}$ & most of the bill for any even, \\
in a battle over who should & $\underline{\underline{\text { foot }}}$ & a multi-million dollar bill f
\end{tabular}

The metaphorical use of the word foot is shared in both languages, but its metaphorical extensions in each language reveal striking differences. English expressions such as to have one's feet on the ground and to put somebody on his feet find equivalences in Chinese: 腳踏實地 and 使某人自立. But Chinese does not allow to foot a bill or to put one's foot in one's mouth. The translation equivalents of these expressions show no trace of foot whatsoever.

Another example of the abandonment of an image occurs with the word nerve.

\begin{tabular}{|rll}
\hline $\begin{array}{l}\text { itory have evolved into a } \\
\text { nerve }\end{array}$ & centre, acting as a control r \\
bond this week and there are & $\underline{\text { nerves }}$ & the US [market] may see a bi \\
tion-related data that calmed & $\underline{\text { nerves }}$ & the US Federal Reserve would \\
summit'' with Beijing calmed & $\underline{\text { nerves, }}$ & but brokers expect market $\mathrm{v}$ \\
600 that had held for months. & $\underline{\text { Nerves }}$ & over dollar weakness and $t$
\end{tabular}




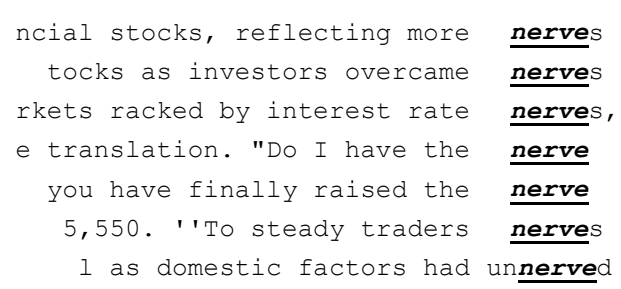

nerves

nerves

nerves,

nerve

nerve

nerves

nerved

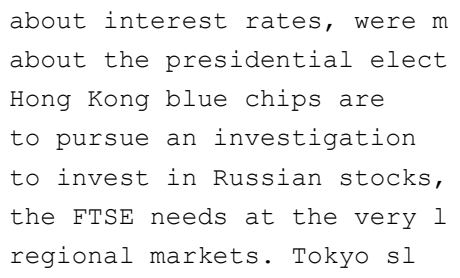

In both English and Chinese, use of the word nerve goes beyond the word's biological sense, extending to central control of emotional functions. The following table compares metaphorical use of the word nerve in each language.

\begin{tabular}{|c|c|c|}
\hline English Metaphor & Meaning & $\begin{array}{c}\text { Chinese Metaphorical } \\
\text { Equivalent }\end{array}$ \\
\hline nerve centre & central control system & $\begin{array}{l}\text { 神經中樞 } \\
\end{array}$ \\
\hline nerve-racking & causing stress or anxiety & 神經緊張 \\
\hline nervous breakdown & $\begin{array}{l}\text { mental illness resulting } \\
\text { from severe stress }\end{array}$ & 神經崩潰 \\
\hline to have/raise the nerve to & to develop the courage to & - \\
\hline to calm nerves & to reduce the tension & 放松/松弛 神經 \\
\hline to reflect nerves & to show worries & - \\
\hline to overcome nerves & to become less worried & - \\
\hline to steady nerves & to soothe & - \\
\hline
\end{tabular}

\section{Conclusions}

Metaphors are particularly prevalent in business texts both in English and in Chinese, and metaphorical meaning often takes pride of place over literal meaning. This tendency has to be taken into consideration when deciding the definition and sense order of entries in a business lexicon.

Every culture has its own 'bags' of metaphors and their meanings also vary in register. Differences lie in individual metaphors used in each language, rather than in conceptual structure. Since the process of communication is a creative experience, metaphors invariably embody cultural values and analogies specific to the contexts from which they spring. Even where similar images are used, for example, there are significant differences in metaphorical collocation and usage between one language and another. It has been shown that different strategies for cultural transformation, such as direct translation, image substitution and abandonment of the figure of speech can be used to bridge interlanguage metaphorical gaps.

\section{References}

Adam, J.H. (Ed.). 1989². Longman Dictionary of Business English. Essex: Longman. 
Andersen, M.S. 2000. Metaphor Matters. Herms: Journal of Linguistics 24: 57-80.

Baldick, C. 1990. The Concise Oxford Dictionary of Literary Terms. Oxford: Oxford University Press.

Crowther, J. (Ed.). 19954. Oxford Advanced Learner's Dictionary. Oxford: Oxford University Press.

Gusun, L.U. (Ed.) 1993. The English-Chinese Dictionary. Unabridged. Shangai: Shangai Translation Press.

Goatly, A. 1997. The Language of Metaphors. London: Routledge.

Lakoff, G. 1993. The Contemporary Theory of Metaphor. Ortony, A. (Ed.). 19932. Metaphor and Thought: 202-251. New York: Cambridge University Press.

Li, Lan and G.T. Bilbow. 2001. From a Business Corpus to a Business Lexicon. Lexikos 11: 209-221.

Mühlhäusler, P. 1983. Towards an Explanatory Theory of Metaphor. Trier: Linguistic Agency.

Newmark, P. 1998. More Paragraphs on Translation. Clevedon/Philadelphia: Multilingual Matters.

Pearsall, J. (Ed.). 1998. The New Oxford Dictionary of English. Oxford: Clarendon Press.

Procter, P. (Ed.). 1995. Cambridge International Dictionary of English. Cambridge: Cambridge University Press.

Sherblom, J.C. 1998. Translation Business Communication by Building on Forman's Translation Metaphor. The Journal of Business Communication 35(1): 74-86.

Snell-Hornby, M. 1988. Translation Studies: An Integrated Approach. Amsterdam/Philadelphia: John Benjamins. 